\title{
PEMENUHAN KEBUTUHAN GIZI ATLET UNTUK MENCAPAI PRESTASI SEPAKBOLA INDONESIA
}

Oleh: Komarudin Dosen Jurusan Pendidikan Olahraga Rekreasi FIK UNY

\begin{abstract}
Abstrak
Sepakbola merupakan salah satu olahraga yang banyak digemari oleh masyarakat di seluruh dunia termasuk di Indonesia. Pembinaan terhadap olahraga ini telah lama dilakukan oleh induk organisasi sepakbola Indonesia (PSSI), namun masih belum menampakkan prestasi yang menggembirakan.

Pemanfaatan dan penerapan ilmu pengetahuan dan teknologi dalam sepakbola modern mutlak harus sudah dilakukan dalam pembinaan sepakbola. Salah satu faktor yang perlu diperhatikan untuk mewujudkan prestasi sepakbola yang tinggi adalah pemanfaatan dan penerapan ilmu gizi olahraga yang benar dan profesional.

Kebutuhan gizi bagi pemain sepakbola meliputi karbohidrat, lemak, protein, vitamin, mineral, air, dan serat. Pemberian makanan bergizi bagi pemain sepakbola dilakukan pada periode pelatihan, periode pertandingan, dan periode pemulihan.
\end{abstract}

Kata kunci: sepakbola, gizi. 
Dewasa ini olahraga telah merupakan kebutuhan hidup manusia hampir di seluruh dunia. Kiranya dapat dibayangkan betapa hambarnya kehidupan manusia andaikan sehari-hari tanpa berita olahraga baik lewat media cetak maupun elektronika. Olahraga telah makin diakui sebagai sarana untuk dapat saling mendekatkan bangsa-bangsa di dunia dalam rangka mengurangi ketegangan dunia serta menciptakan perdamaian dunia yang menjadi idaman setiap orang.

Dengan makin ketatnya persaingan untuk mencapai prestasi tinggi dalam olahraga, sejalan pula dengan motto Olympic Games, yaitu: citius, altius, foltius, orang lalu berupaya untuk dapat meraih prestasi olahraga setinggi-tingginya. Meskipun dalam olimpiade telah dinyatakan bahwa pertandingan itu bukanlah antarnegara melainkan antarperorangan dan regu yang bertanding, seperti yang tercantum dalam peraturan 9 dari Olympic Charter, dalam kenyataanya, atlet yang bertanding pada forum olimpiade telah menjadi milik masyarakat pemerintah negaranya. Atlet yang berlaga dan bertanding tidak saja ditunjang oleh keluarga maupun perkumpulannya akan tetapi juga didukung oleh masyarakat dan pemerintahnya.

Demikian pula yang terjadi di Indonesia, atlet yang terpilih untuk mewakili Indonesia ke olimpiade pembiayaannya didukung oleh masyarakat (KONI) dan pemerintah (Menpora). Seiring dengan kemajuan ilmu pengetahuan dan teknologi, pembangunan di bidang olahraga pada umumnya dan olahraga prestasi pada khususnya tidak pelak lagi harus menerapkan ilmu pengetahuan dan teknologi maju.

Dalam konteksnya dengan pembinaan prestasi sepakbola Indonesia, pemanfaatan dan penerapan ilmu pengetahuan dan teknologi dalam sepakbola modern mutlak harus sudah dilakukan dalam pembinaan sepakbola. Salah satunya adalah dengan pemanfaatan dan penerapan ilmu gizi olahraga yang benar dan profesional sebagai faktor pendukung yang besar pengaruhnya.

\section{OLAHRAGA SEPAKBOLA}

Olahraga permainan sepákbola sangat membutuhkan energi tinggi dan dapat disetarakan dengan kebutuhan energi/kalori pekerja sangat berat. Sebagaimana dikatakan Joe Luxbacher (1999: 11) bahwa permainan sepakbola

MEDIKORA Vol. II, No. 2, Oktober 2006: 119 - 134. 
merupakan permainan yang berlangsung sangat cepat, dalam waktu yang relatif lama. Gerakan-gerakan yang dilakukan oleh pemain berupa lari, tendang, loncat, dan sprint-sprint pendek yang persentasenya cukup besar. Gerakan lain yang khas dan dominan dalam permainan sepakbola adalah menggiring bola, benturan dengan lawan, dan heading bola.

Lebih lanjut, Peter Treadwell (1991: 37) mengemukakan bahwa permainan sepakbola memerlukan keterampilan yang berhubungan dengan kebugaran tubuh, yaitu kekuatan atau daya ledak otot, kecepatan, dan kelincahan. Daya ledak otot adalah kemampuan otot untuk melakukan kontraksi otot dengan sangat cepat, yang sangat dipengaruhi oleh kekuatan otot. Kecepatan dalam bermain sepakbola memerlukan kesegaran jasmani atau kebugaran. Disisi lain, kelincahan seorang pemain sepakbola untuk bergerak cepat dan mengubah arah dan posisi secara tepat membutuhkan keseimbangan tubuh dan keterampilan yang tinggi.

Kekuatan otot yang tinggi sangat diperlukan oleh pemain sepakbola untuk berlari cepat, menendang bola, melempar bola, mempertahankan keseimbangan tubuh, dan mencegah terjatuh saat benturan dengan pemain lawan. Selain itu, permainan ini membutuhkan daya tahan jantung-paru yang menggambarkan kapasitas untuk melakukan aktivitas secara terus menerus dalam waktu lama tanpa mengalami kelelahan yang berarti.

Daya tahan jantung-paru pemain sepakbola dapat ditingkatkan dengan latihan daya tahan jantung-paru atau latihan aerobik dengan melakukan interval training (Bompa, 1994: 59). Prinsip interval training mengandung komponen lama latihan, intensitas latihan, masa istirahat, dan pengulangan. Contoh: lari atau berenang. Berdasarkan karakteristik permainan sepakbola seperti di atas, untuk dapat mencapai prestasi yang optimal, pemain sepakbola harus memenuhi persyaratan tertentu. Bentuk tubuh pemain sepakbola harus ideal, yaitu: sehat, kuat, tinggi, dan tangkas. Seorang pemain sepakbola harus mempunyai indeks massa tubuh (IMT) yang normal dengan tinggi badan (TB) di atas rata-rata. Komposisi tubuh harus proporsional antara massa otot dan lemak. Tidak boleh ada lemak yang berlebih (Nancy Clark, 2001: 23).

Oleh karena itu, untuk menjadi pemain sepakbola dengan bentuk tubuh yang ideal, dan aktivitas yang prima diperlukan program pelatihan yang teratur dan terarah. Program pelatihan itu adalah pelatihan beban untuk meningkatkan 
kekuatan otot, pelatihan peregangan untuk memperkuat kelenturan tubuh, dan pelatihan aerobik untuk meningkatkan kebugaran serta pelatihan teknik dan keterampilan.

Semua upaya di atas, akan mencapai hasil yang lebih baik dengan asupan gizi atau pengaturan makanan dengan kebutuhan gizi yang lebih besar dibanding orang biasa. Hal ini yang harus disadari dan dipahami oleh pemain sepakbola, pelatih, dan keluarga serta lingkungannya agar selalu menjaga kondisi kesehatannya dengan asupan gizi atau pengaturan makanan yang seimbang. Dalam hal ini Nancy Clark, (2001: 21) mengemukakan bahwa pengaturan makanan khusus harus disiapkan pada masa pelatihan, pertandingan, dan pascapertandingan.

\section{KEBUTUHAN GIZI}

Sesuai prinsip "gizi seimbang" yang mengandung cukup karbohidrat, lemak, protein, vitamin, mineral, air, dan serat (Ditjen Binkesmas, 2002: 5), kebutuhan gizi atlet sepakbola adalah sebagai berikut:

\section{Energi}

Secara umum seorang pemain sepakbola memerlukan energi sekitar 4.500 Kkal atau 1,5 kali kebutuhan energi orang dewasa normal dengan postur tubuh relatif sama, karena pemain sepakbola dikategorikan dengan seseorang yang melakukan aktivitas fisik yang berat. Kebutuhan energi dihitung dengan memperhatikan beberapa komponen penggunaan energi, yaitu: basal metabolic rate (BMR), specific dynamic action (SDA), aktivitas fisik dan faktor pertumbuhan (Ditjen Binkesmas, 1977: 37).

\section{a. Basal Metabolic Rate (BMR)}

BMR merupakan jumlah energi yang dikeluarkan untuk aktivitas vital tubuh seperti denyut jantung, bernapas, dan transmisi elektrik pada otot dan lain-lain.

MiEnIKORA Vol. II, No. 2, Oktober 2006: 119 - 134. 
Tabel 1. BMR untuk Laki-laki Berdasarkan Berat Badan

\begin{tabular}{|c|c|c|c|c|}
\hline \multirow{2}{*}{$\begin{array}{c}\text { Jenis } \\
\text { Kelamin }\end{array}$} & \multirow{2}{*}{ Berat Badan } & \multicolumn{3}{|c|}{ Energi (Kal) } \\
\cline { 2 - 5 } & & $\mathbf{1 0 - \mathbf { 1 8 } \text { TH }}$ & $\mathbf{1 8 - 3 0} \mathbf{~ T H}$ & $\mathbf{3 0 - 6 0 ~ T H}$ \\
\hline Laki-laki & 55 & 1625 & 1514 & 1499 \\
\cline { 2 - 5 } & 60 & 1713 & 1589 & 1556 \\
\cline { 2 - 5 } & 65 & 1801 & 1664 & 1613 \\
\cline { 2 - 5 } & 70 & 1889 & 1739 & 1670 \\
\cline { 2 - 5 } & 75 & 1977 & 1814 & 1727 \\
\cline { 2 - 5 } & 80 & 2065 & 1889 & 1785 \\
\cline { 2 - 5 } & 85 & 2154 & 1964 & 1842 \\
\cline { 2 - 5 } & 90 & 2242 & 2039 & 1899 \\
\hline
\end{tabular}

(Sumber: Ditjen Binkesmas, 2002)

Tabel 2. BMR untuk Perempuan Berdasarkan Berat Badan

\begin{tabular}{|c|c|c|c|c|}
\hline \multirow{2}{*}{$\begin{array}{c}\text { Jenis } \\
\text { Kelamin }\end{array}$} & \multirow{2}{*}{ Berat Badan } & \multicolumn{3}{|c|}{ Energi (Kal) } \\
\cline { 2 - 5 } & & $\mathbf{1 0 - \mathbf { 1 8 } \mathbf { T H }}$ & $\mathbf{1 8 - 3 0} \mathbf{~ T H}$ & $\mathbf{3 0 - 6 0} \mathbf{~ T H}$ \\
\hline Perempuan & 40 & 1224 & 1075 & 1167 \\
\cline { 2 - 5 } & 45 & 1291 & 1149 & 1207 \\
\cline { 2 - 5 } & 50 & 1357 & 1223 & 1248 \\
\cline { 2 - 5 } & 55 & 1424 & 1296 & 1288 \\
\cline { 2 - 5 } & 60 & 1491 & 1370 & 1329 \\
\cline { 2 - 5 } & 65 & 1557 & 1444 & 1369 \\
\cline { 2 - 5 } & 70 & 1624 & 1518 & 1410 \\
\cline { 2 - 5 } & 75 & 1691 & 1592 & 1450 \\
\hline
\end{tabular}

(Sumber: Ditjen Binkesmas, 2002)

\section{b. Specific Dynamic Action(SDA)}

SDA merupakan jumlah energi yang dibutuhkan untuk mengolah makanan dalam tubuh, antara lain untuk proses pencernaan dan penyerapan zatzat gizi oleh usus. Besarnya SDA kurang lebih $10 \%$ dari BMR. 


\section{c. Aktivitas Fisik}

Pengeluaran energi untuk aktivitas fisik harian ditentukan oleh jenis, intensitas, dan lamanya aktivitas fisik dan olahraga.

Tabel 3. Rata-rata Tingkat Aktivitas Harian (di luar latihan)

\begin{tabular}{|l|c|c|}
\hline \multirow{2}{*}{\multicolumn{1}{|c|}{ Tingkat Aktivitas }} & \multicolumn{2}{c|}{ Jenis Kelamin } \\
\cline { 2 - 3 } & Laki-laki & Perempuan \\
\hline Istirahat di tempat tidur & 1,2 & 1,2 \\
\hline Kerja sangat ringan & 1,4 & 1,4 \\
\hline Kerja ringan & 1,5 & 1,5 \\
\hline Kerja ringan-sedang & 1,7 & 1,6 \\
\hline Kerja sedang & 1,8 & 1,7 \\
\hline Kerja berat & 2,1 & 1,8 \\
\hline Kerja berat sekali & 2,3 & 2,0 \\
\hline
\end{tabular}

(Sumber: Ditjen Binkesmas, 2002)

Tabel 4. Kebutuhan Energi Aktivitas Olahraga Berdasarkan Berat Badan(Kalori/menit)

\begin{tabular}{|l|c|c|c|c|c|}
\hline \multirow{2}{*}{ Aktivitas } & \multicolumn{5}{|c|}{ Berat Badan(Kg) } \\
\cline { 2 - 6 } & $\mathbf{5 0}$ & $\mathbf{6 0}$ & $\mathbf{7 0}$ & $\mathbf{8 0}$ & $\mathbf{9 0}$ \\
\hline \multicolumn{1}{|c|}{$(1)$} & $(2)$ & $(3)$ & $(4)$ & $(5)$ & $(6)$ \\
\hline Sepakbola & 7 & 8 & 9 & 10 & 12 \\
\hline Lari: & & & & & \\
\hline$-5,5 \mathrm{menit} / \mathrm{km}$ & 10 & 12 & 14 & 15 & 17 \\
\hline-5 menit/km & 10 & 12 & 15 & 17 & 19 \\
\hline$-4,5$ menit/km & 11 & 13 & 15 & 18 & 20 \\
\hline-4 menit $/ \mathrm{km}$ & 13 & 15 & 18 & 21 & 23 \\
\hline Jalan Kaki: & & & & & \\
\hline-10 menit/km & 5 & 6 & 7 & 8 & 9 \\
\hline-8 menit/km & 6 & 7 & 8 & 10 & 11 \\
\hline-5 menit $/ \mathrm{km}$ & 10 & 12 & 15 & 17 & 19 \\
\hline
\end{tabular}

(Sumber: Ditjen Binkesmas, 2002) 


\section{d. Pertumbuhan}

Anak dan remaja mengalami pertumbuhan sehingga memerlukan penambahan energi. Energi tambahan dibutuhkan untuk pertumbuhan tulang baru dan jaringan tubuh (Sunita Almatsier, 2003: 35).

Tabel 5. Kebutuhan Energi Untuk Pertumbuhan (Kalori/hari)

\begin{tabular}{|l|c|l|}
\hline \multicolumn{1}{|c|}{ Jenis Kelamin } & Umur(Tahun) & \multicolumn{1}{c|}{ Tambahan E nergi } \\
\hline $\begin{array}{l}\text { Anak Laki-laki dan } \\
\text { Perempuan }\end{array}$ & $10-14$ & $2 \mathrm{kalori} / \mathrm{kg}$ berat badan \\
\cline { 2 - 3 } & 15 & $\begin{array}{l}1 \mathrm{kalori} / \mathrm{kg} \\
\text { berat badan }\end{array}$ \\
\cline { 2 - 3 } & $16-18$ & $\begin{array}{l}0,5 \mathrm{kalor} / \mathrm{kg} \\
\text { berat badan }\end{array}$ \\
\hline
\end{tabular}

(Sumber: Ditjen Binkesmas, 2002)

Rumus : Perhitungan jumlah energi yang dikeluarkan setiap orang atau setiap atlet.

$$
\mathrm{BMR}+\mathrm{SDA}+\mathrm{AKTIVITAS} \text { FISIK }
$$

\section{Cara Menghitung Kebutuhan Energi:}

Ada enam langkah dalam menghitung kebutuhan energi (Nancy Clark, 2001: 51) yaitu:

\section{Langkah 1}

Menentukan status gizi atlet dengan menggunakan dan persentase lemak tubuh. IMT merupakan pembagian berat badan dalam kg oleh TB dalam satuan meter dikuadratkan. Persentase lemak tubuh yaitu perbandingan antara lemak tubuh dan massa tubuh tanpa lemak. Pengukuran lemak tubuh dilakukan dengan menggunakan alat skinfold caliper pada daerah trisep dan subskapula. 


$$
\text { Rumus IMT }=\frac{\text { Berat Badan }(\mathrm{Kg})}{\text { Tinggi Badan }(\mathrm{m}) \times \text { Tinggi Badan }(\mathrm{m})}
$$

Batas ambang IMT adalah sebagai berikut:

Tabel 6. Batas Ambang IMT

\begin{tabular}{|l|l|c|}
\hline \multicolumn{1}{|c|}{ Keadaan } & \multicolumn{1}{|c|}{ Kategori } & IMT \\
\hline Kurus & $\begin{array}{l}\text { Kekurangan berat badan tingkat } \\
\text { berat }\end{array}$ & $<17$ \\
\cline { 2 - 3 } & $\begin{array}{l}\text { Kekurangan berat badan } \\
\text { tingkat ringan }\end{array}$ & $17,0-18,4$ \\
\hline Normal & $\begin{array}{l}\text { Kelebihan berat badan } \\
\text { tingkat ringan }\end{array}$ & $18,5-25,0$ \\
\cline { 2 - 3 } & $\begin{array}{l}\text { Kelebihan berat badan } \\
\text { tingkat berat }\end{array}$ & $>27$ \\
\hline
\end{tabular}

\section{Langkah 2}

Menentukan BMR yang sesuai dengan jenis kelamin, umur, dan BB (lihat tabel 1 dan 2), menambahkan BMR dengan SDA yang besarnya $10 \%$ BMR.

$$
\mathrm{BMR}+\mathrm{SDA}(10 \% \mathrm{BMR})
$$

\section{Langkah 3}

Menentukan faktor tingkat aktivitas fisik setiap hari (tanpa kegiatan olahraga) sesuai yang tertera dalam tabel 3 .

\section{Langkah 4}

Mengalikan BMR yang telah ditambah SDA dengan faktor tingkat aktivitas fisik yang tertera dalam tabel 3 .

\section{Langkah 5}

Menentukan penggunaan energi sesuai dengan latihan atau pertandingan sepakbola dengan menggunakan tabel 4. Mengalikan jumlah jam yang

MEDIKORA Vol. II, No. 2, Oktober 2006: 119 - 134. 
digunakan untuk latihan per minggu dengan besar energi yang dikeluarkan untuk setiap latihan olahraga. Total perhitungan energi yang didapat dari perhitungan dalam seminggu, kemudian dibagi 7 untuk mendapatkan penggunaan energi yang dikeluarkan per hari. Menambahkan besarnya penggunaan energi ini dengan besarnya energi yang didapatkan pada langkah 4 .

\section{Langkah 6}

Apabila atlet tersebut dalam usia pertumbuhan, di tambahkan kebutuhan energi sesuai tabel 5 .

\section{ContohPerhitungan}

Andi seorang pemain sepakbola, umur 19 tahun, mempunyai berat badan $60 \mathrm{~kg}$., tinggi badan $160 \mathrm{~cm}$. Untuk menjaga staminanya ia berlatih berlari dengan kecepatan 5,5 menit per km, selama satu jam, tiga kali per minggu. Andi berlatih sepakbola 3 kali per minggu dengan lama setiap latihan 90 menit. Aktivitas Andi di luar kegiatan olahraga termasuk sedang. Berapa kebutuhan energi Andi setiap hari?

\section{Langkah 1}

Menentukan status gizi atlet dengan menggunakan IMT dan persentase lemak.

$$
\operatorname{IMT}=\frac{60}{1,6 \times 1,6}=23,4
$$

Berdasarkan perhitungan tersebut, IMT Andi termasuk normal.

\section{Langkah 2}

BMR $=1.589 \mathrm{kal}$. (lihat tabel 1)

SDA $10 \%=10 \% \times 1.589=158,9$

Menjumlahkan BMR dengan SDA yaitu $1.589+158,9=1.747,9$ kalori

\section{Langkah 3 dan 4}

Faktor tingkat aktivitas sedang $=1,8$ (lihat tabel 3)

$1,8 \times 1.747,9=3.146,2 \mathrm{kal}$. 


\section{Langkah 5}

Kebutuhan energi untuk aktivitas lari 5,5 menit/km dengan BB $60 \mathrm{~kg}$ adalah $12 \mathrm{kal} / \mathrm{menit}$ dan untuk sepakbola $8 \mathrm{kal} /$ menit (lihat tabel 4), sehingga untuk tiap minggu:

- berlatih lari $=(3 \times 60$ menit $\times 12 \mathrm{kal})=2.160 \mathrm{kal} / \mathrm{minggu}$

- berlatih sepakbola $=(3 \times 90$ menit $\times 8 \mathrm{kal})=2.160 \mathrm{kal} / \mathrm{minggu}$

Jadi kebutuhan $\mathrm{kalori} /$ minggu untuk berlatih lari dan sepakbola adalah = $4.320 \mathrm{kal}$ atau sama dengan $617,1 \mathrm{kal} / \mathrm{hari}$. Total energi yang dibutuhkan per hari $=(3.146,2+617,1) \mathrm{kal}=3.763,3 \mathrm{kal} /$ hari .

\section{Karbohidrat}

Karbohidrat merupakan sumber utama energi untuk memenuhi kebutuhan gizi bagi atlet sepakbola. Ali Khomsan (2004: 41) mengemukakan bahwa jenis makanan sumber karbohidrat antara lain: biji-bijian (beras, ketan, jagung), umbi-umbian (ubi, singkong), dan tepung-tepungan (roti, mie,pasta, makaroni, bihun).

\section{Protein}

Protein merupakan zat gizi. Protein asal hewani seperti daging penghasil energi yang tidak berperan sebagai sumber energi tetapi berfungsi untuk mengganti jaringan dan sel tubuh yang rusak. Protein bagi atlet sepakbola yang masih remaja sangat diperlukan untuk pertumbuhan dan pembentuk tubuh guna mencapai tinggi badan yang optimal. Atlet sepakbola sangat dianjurkan untuk mengkonsumsi sumber protein yang berasal dari hewani dan nabati. Protein asal hewani seperti daging (dianjurkan daging yang tidak berlemak), ayam, ikan, telur, dan susu. Ali Khomsan (2004: 46) mengemukakan bahwa sumber protein nabati yang dianjurkan adalah tahu, tempe, dan kacang-kacangan (kacang tanah, kedelai dan kacang hijau).

\section{Lemak}

Walaupun lemak merupakan sumber energi yang paling tinggi, para atlet tidak dianjurkan untuk mengkonsumsi lemak berlebihan, karena energi lemak tidak dapat langsung dimanfaatkan untuk latihan maupun bertanding. Lemak terdapat dalam makanan asal hewan sebagai lemak hewani dan asal

MEDIKORA Vol. II, No. 2, Oktober 2006: 119 - 134. 
tumbuhan sebagai lemak nabati. Lemak hewani contohnya adalah: keju, mentega, lemak daging (sapi/kambing). Contoh lemak nabati adalah: minyak sawit, minyak kelapa, margarin, minyak kedelai, minyak kacang, dan minyak jagung (Ditjen Binkesmas, 2002: 51).

\section{Vitamin}

Vitamin B1 dan vitamin B lainnya yang tergolong ke dalam vitamin B kompleks berperan penting dalam proses pembentukan energi. Vitaminvitamin lainnya dibutuhkan dalam jumlah besar, seperti vitamin A, C, dan E untuk kebutuhan metabolisme zat-zat gizi lainnya. Vitamin D dibutuhkan untuk pembentukan tulang bagi atlet sepakbola yang masih remaja (Sunita Almatsier. 2003: 41).

Sumber vitamin A adalah sayur dan buah-buahan berwarna hijau tua/ merah seperti wortel, tomat, daun singkong, daun katuk, pepaya, mangga. Sumber vitamin C adalah jambu biji, pepaya, jeruk, belimbing, dan sumber vitamin E adalah daging, ikan, sayuran hijau, minyak jagung, minyak kedelai. Atlet sepakbola terutama remaja dianjurkan untuk berjemur setiap pagi untuk memperkuat pembentukan tulang.

Vitamin banyak terdapat dalam makanan sumber asal hewani seperti daging, telur, ikan, dan ayam. Selain itu, vitamin juga bisa didapatkan dari sumber asal nabati, seperti sayuran dan buah-buahan segar. Atlet sepakbola dianjurkan selain mengkonsumsi makanan asal hewani juga perlu mengkonsumsi makanan asal tumbuhan berupa buah-buahan dan sayuran segar.

\section{Mineral}

Atlet sepakbola memerlukan oksigen yang lebih banyak untuk pembakaran karbohidrat yang menghasilkan energi terutama pada saat bermain. Untuk mengangkut oksigen $\left(\mathrm{O}_{2}\right)$ ke otot diperlukan hemoglobin $\mathrm{Hb}$ atau sel darah merah yang cukup. Untuk membentuk Hb yang cukup, tubuh memerlukan zat besi (Fe) yang bersumber dari daging (dianjurkan daging yang tidak berlemak), sayuran hijau dan kacang-kacangan. Oleh karena itu, atlet sepakbola tidak boleh menderita anemia, agar dapat berprestasi.

Atlet sepakbola yang masih remaja memerlukan kalsium yang relatif lebih tinggi untuk pertumbuhan tulangnya. Sumber kalsium bisa didapatkan

Pemenuhan Kebutuhan Gizi Atlet untuk Mencapai Prestasi Sepakbola Indonesia (Komarudin) 
dari susu rendah lemak (skim milk). Oleh karena itu, atlet sepakbola yang masih remaja sangat dianjurkan untuk mengkonsumsi susu setiap hari agar mencapai tinggi badan optimal. Ikan juga merupakan sumber kalsium terutama ikan yang dikonsumsi dengan tulangnya (contoh: ikan teri). Selain itu, tulang ikan juga mengandung fluor untuk melindungi gigi agar tidak berlubang (Nancy Clark, 2001: 23).

Zat-zat mineral lainnya seperti seng ( $\mathrm{Zn}$ ) dan selenium (Se) berfungsi sebagai antioksidan yang dapat menghambat terbentuknya radikal bebas yang berlebihan sehingga dapat mencegah kerusakan sel tubuh. Mineral bisa didapatkan dari makanan sumber hewani maupun sumber nabati. Sumber Zn dan Se, antara lain: sea food dan daging.

\section{Air dan Elektrolit}

Saat berlatih maupun bertanding, atlet sepakbola akan mengeluarkan keringat dalam jumlah yang sangat banyak. Keringat akan lebih banyak lagi dikeluarkan apabila berolahraga di tempat panas. Air keringat yang keluar dari tubuh dapat mencapai satu liter per jam. Apabila tubuh kehilangan air melebihi $2 \%$ dari total berat badan, seseorang akan mengalami dehidrasi (kekurangan cairan) dan dapat terganggu kesehatannya.

Untuk mencegah dehidrasi, ada baiknya atlet sepakbola minum sebelum merasa haus. Minum air yang teratur dengan tambahan sedikit elektrolit dan karbohidrat sangat baik untuk mencegah terjadinya dehidrasi. Nancy Clark. (2001: 25) mengemukakan bahwa air minum yang diminum dianjurkan berupa jus dari buah-buahan karena selain mengandung air juga mengandung elektrolit yang dibutuhkan untuk mengganti cairan maupun elektrolit yang hilang selama latihan atau pertandingan.

Suplemen zat gizi yang berupa obat, makanan atau minuman yang banyak beredar di pasaran dengan berbagai merk hanya diperuntukan untuk atlet pada kondisi tertentu. Hati-hati dalam mengkonsumsi suplemen secara berlebihan, lebih baik berkonsultasi dengan dokter terlebih dahulu.

\section{Serat}

Hal lain yang juga tidak boleh diabaikan oleh atlet sepakbola adalah konsumsi serat (fiber) dari makanan. Ali Khomsan (2004: 27) mengemukakan

MEDIKORA Vol. II, No. 2, Oktober 2006: 119 - 134. 
bahwa konsumsi serat yang cukup dapat membantu buang air besar menjadi teratur dan lancar. Serat juga sangat penting dalam pencegahan berbagai penyakit, misalnya: penyakit kanker usus dan juga penyakit jantung. Serat dari makanan adalah sayur-sayuran dan buah-buahan seperti: bayam, kangkung, daun singkong, daun labu, apel, dan bangkuang.

\section{PENGATURAN MAKAN}

Tujuan pengaturan makanan pada atlet sebagaimana dikemukakan Nancy Clark. (2001: 33) adalah:

1. Memperbaiki dan mempertahankan status gizi agar tidak terjadi kurang gizi atau gizi lebih (kegemukan).

2. Membentuk otot dan mencapai tinggi badan optimal.

3. Memelihara kondisi tubuh dan menjaga kesegaran jasmani.

4. Membiasakan atlet mengatur diri sendiri untuk makan makanan yang seimbang.

\section{PeriodePelatihan}

Pengaturan makanan periode pelatihan selain dilaksanakan di pusat pelatihan juga harus dilakukan pada saat berada di rumah. Prinsip utama pengaturan makanan pada periode ini adalah tersedianya energi yang cukup untuk berlatih dan untuk menghindari pencernaan masih bekerja pada waktu pelatihan sedang berlangsung. Selain memperhatikan kandungan zat gizi dari makanan, pengaturan makanan juga harus memperhatikan pola latihan yang diterapkan. Selain sebagai sumber energi, bahan makanan yang dipilih harus juga mengandung berbagai macam vitamin dan mineral, sehingga kebutuhan zat gizi lainnya juga dapat terpenuhi.

Seusai latihan, makanan yang dikonsumsi harus mengandung energi yang cukup, terutama makanan yang mengandung karbohidrat, mineral, dan air untuk mengganti cadangan energi yang telah dipakai selama latihan. Atlet harus menjaga berat badan yang normal, hindari berat badan berlebih. Atlet juga harus diperkenalkan dengan berbagai macam hidangan yang disediakan. 


\section{Periode Pertandingan}

Makanan untuk atlet diatur agar tidak mengganggu pencernaan sewaktu pertandingan. Selain itu, makanan yang dihidangkan harus mengandung gizi seimbang dan sudah dikenal oleh atlet (atlet sudah biasa mengkonsumsi makanan tersebut). Makanan yang dihidangkan tersebut harus mempunyai nilai psikologis yang baik sehingga terciptalah semboyan eat to win (makan untuk menang).

\section{a. Prapertandingan}

Kira-kira 3-4 jam sebelum pertandingan, atlet dapat mengkonsumsi makanan lengkap. Makanan sebaiknya mudah dicerna, rendah lemak, rendah serat, dan tidak menyebabkan masalah pada pencernaan atlet (tidak terlalu pedas, dan tidak mengandung bumbu-bumbu tajam serta tidak berlemak). Makanan kecil/minuman (biskuit, teh manis, jus buah, dll) bisa diberikan kira-kira 1-2 jam sebelum pertandingan.

\section{b. Selama Pertandingan}

Minum air sebanyak 1-1,5 gelas 1 jam sebelum pertandingan dan saat istirahat (waktu jeda) sangat dianjurkan. Minum air selama pertandingan juga harus dilakukan setiap ada kesempatan, jangan menunggu sampai timbul rasa haus. Air minum dapat ditambah 1 sendok teh gula dan $1 / 4$ sendok teh garam dalam 1 gelas air.

\section{c. Pascapertandingan}

Segera setelah selesai pertandingan, atlet harus segera minum air dingin (suhu 10-15 celcius) sebanyak satu gelas. Kemudian dapat dilanjutkan dengan sari buah/air + gula + garam. Dapat juga diberikan makanan padat yang mudah dicerna seperti biskuit atau bubur halus dalam porsi kecil.

Setelah rasa letih berkurang, lebih kurang 3-4 jam setelah pertandingan, atlet dapat diberikan makanan biasa dengan gizi seimbang sesuai dengan kebutuhan.

\section{PeriodePemulihan(Recovery)}

Periode setelah pertandingan atau periode istirahat aktif, atlet dapat makan makanan biasa untuk mempertahankan dan meningkatkan kondisi fisik. Pada

MEDIKORA Vol. II, No. 2, Oktober 2006: 119 - 134. 
prinsipnya makanan pada periode recovery sama dengan makanan pada periode pelatihan. Pemantauan status gizi secara berkala harus tetap dilaksanakan pada periode ini dan juga periode latihan. Misalnya dengan menimbang berat badan setiap hari dan mengukur tinggi badan setiap bulan untuk menghitung IMT.

\section{PENYUSUNAN MENU}

Menu makanan bagi atlet sepakbola disusun berdasarkan kebutuhan energi yang berbeda untuk setiap atlet. Secara umum Nancy Clark (2001: 43) mengemukakan bahwa faktor yang harus dipertimbangkan adalah:

1. BMR yaitu energi yang dipakai untuk aktivitas metabolisme jaringan tubuh pada waktu istirahat.

2. SDA adalah penggunaan energi yang dipakai untuk proses penyerapan dan pencernaan makanan yang berbeda untuk setiap zat gizi (karbohidrat, lemak, protein, vitamin, mineral, air, dan serat).

3. Aktivitas sehari-hari termasuk olahraga.

4. Pertumbuhan.

Di samping itu, menu makanan untuk atlet sepakbola harus beraneka ragam memenuhi kebutuhan energi, cukup tinggi karbohidrat (60-70\%), rendah lemak ( $<25 \%$ ), cukup protein (1 gram/kg BB/hari) dan cukup vitamin, mineral, serta cukup air. Makanan diberikan dalam porsi kecil dan sedang, serta dihindari makanan yang berbumbu tajam (terlalu pedas, terlalu asam, dan terlalu berlemak). Makanan tidak menimbulkan gas dan cukup serat serta telah dikenal oleh atlet.

Masalah yang seringkali timbul dalam menyediakan makanan bagi atlet adalah menu makanan yang membosankan, atlet malas makan karena letih, atlet suka makanan jajanan, sehingga kecukupan gizi kemungkinan tidak dapat terpenuhi atau sebaliknya malah berlebih. Dalam hal ini perlu diberikan pemahaman tentang gizi bagi atlet itu sendiri, pelatih serta keluarganya.

\section{KESIMPULAN}

Proses pembinaan prestasi olahraga Indonesia sudah saatnya dilakukan juga dengan usaha pemanfaatan dan penerapan ilmu pengetahuan dan teknologi. Demikian pula halnya dengan pembinaan prestasi sepakbola, penerapan Iptek 
harus sudah dilakukan, salah satunya adalah dengan pemanfaatan dan penerapan ilmu gizi olahraga yang benar dan profesional sebagai faktor pendukung yang besar pengaruhnya.

Pengetahuan tentang pemanfaatan dan penerapan gizi olahraga khususnya bagi atlet sepakbola harus benar-benar dipahami oleh pemain sepakbola, pelatih, dan keluarga serta lingkungannya agar selalu terjaga kondisi kesehatannya dengan asupan gizi atau pengaturan makanan yang seimbang, yang pada akhirnya nanti dapat mempunyai peran yang signifikan dalam upaya pembinaan prestasi sepakbola Indonesia.

\section{DAFTAR PUSTAKA}

Ali Khomsan. (2004). Pangan dn Gizi untuk Kesehatan. Jakarta: Raja Grafindo Persada.

Bompa, Tudor O. (1994). Theory and Methodology of Training. Dubuque, Iowa: Kendall/Hunt Publishing Company.

Ditjen Binkesmas. (1977). Gizi Olahraga untukPrestasi. Jakarta: Direktorat Bina Gizi Masyarakat, Depkes RI.

(2002). Pedoman Umum Gizi Seimbang. Jakarta: Direktorat Gizi Masyarakat, Depkes RI.

Luxbacher, Joe. (1999). Sepakbola: Taktikdan Teknik Bermain. Jakarta: PT Raja Grafindo Persada.

Nancy Clark. (2001). Petunjuk Gizi untuk Setiap Cabang Olabraga. Jakarta: Raja Grafindo Persada.

Sunita Almatsier. (2003). Prinsip Dasar Ilmu Gizi. Jakarta: Gramedia Pustaka Utama Treadwell, Peter. (1991). Skillfull Soccer. London: A\&C Black.

MEDIKORA Vol. II, No. 2, Oktober 2006: 119 - 134. 